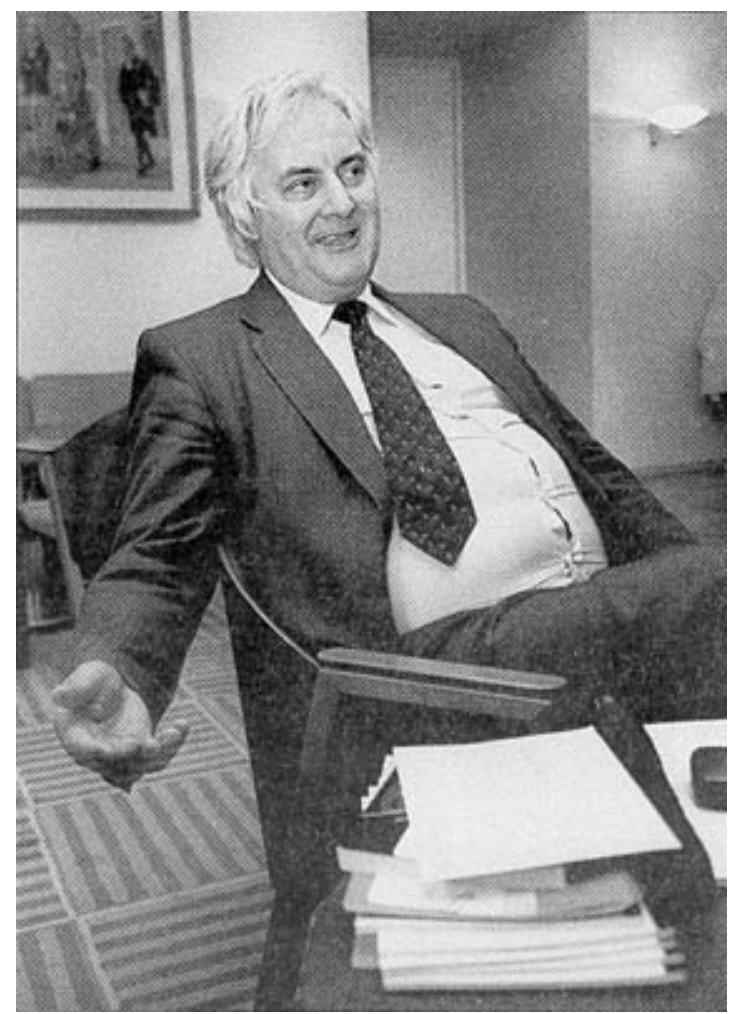

\begin{abstract}
Peter Jarvis, Surreyn yliopiston aikuiskasvatuksen professori, on taustoiltaan monenlaista, mm. pappi. Hänet tunnetaan henkilönä, joka sukkuloi kiintoisalla tavalla filosofian, sosiologian ja aikuiskasvatuksen maailmassa nostaen esiin uudenlaisia näkökulmia ihmisen kasvuun ja oppimiseen.
\end{abstract}

"Kiehtovinta ajassamme ei ole se, elämmekö modernia, myöhäismodernia vai postmodernia aikaa, vaan se, että elämme aikaa, jolloin voimme tehdä itsestäänselvyyksiä kyseenalaistavia kysymyksiä tarvitsematta tuntea itseämme kummallisiksi", hän sanoo.

\title{
Peter Jarvis - monitieteisyyden ja tieteiden välisen yhteistyön apostoli
}

Professori Peter Jarvis tunnetaan tuotteliaana miehenä. Hän on Intemational Journal of Lifelong Education -lehden päätoimittaja. Lehti ilmestyy kuusi kertaa vuodessa ja Jarvis on toiminut sen päätoimittajana 14 vuotta. Peter Jarvis on myös tuottelias artikkeleiden ja kirjojen kirjoittaja. Kirjastaan "Adult Leaming in the Social

Context" (London 1987) hän on saanut arvostetun amerikkalaisen Cyril Hoyle -palkinnon.

Miten arvioitte itse kirjallista toimintaanne: onko juuri oppiminen kontekstissa erityinen tyytyväisyyttä tuottanut alueenne vai jokin тии?

PETER JARVIS:

jos joudun nimeämään yhden asian, niin siinä tapauksessa se on Intemational Journal of Lifelong Education. Enemmän kuin omista varsinaisista töistäni olen kuitenkin ylpeä aikaansaamistani kirjasarjoista, joiden kautta olen voinut auttaa muita julkaisemaan. Mark Tennant Australiasta on yksi niistä kirjoittajista, joka on myös saanut minun sarjassani ilmestyneellä kirjallaan saman Cyril Hoyle-palkinnon.

"Adult Learning in the Social Context"-kirjan jälkeen ilmestyi amerikkalaisen Jossey-Bassin kustantamana "Paradoxes of Learning" vuonna 1992. Pidän sitä paljon parempana, koska se on 
omaperäisempi. Eräässä mielessä Paradoxes of Leaming heijastelee ajatuksiani myöhäismodernin yhteiskunnan epäselvyydestä ja kaksiselitteisyydestä. Kirjan teko johdatti minut ajattelemaan filosofian ja kasvatuksen aiheita rinnakkain.

Tcoksen "Adult and Continuing Education: Theory and Practise" tarkistettu painos ilmestyi viime vuonna (1995). Se on yhdestoista kirjoittamani kirja, sillä se on melko lailla erilainen ja lähes uuden kirjan veroinen verrattuna aiempaan vastaavaan kirjaani. Tänä vuonna ilmestyy kirjani aikuiskasvatuksen etiikasta. Itse kirjoittamieni kirjojen lisäksi olen ollut toimittamassa monia teoksia sekä kahta sarjaa, joissa on ilmestynyt yhteensä noin 50 kirjaa.

\section{Generalistina tieteenalojen välimaastossa}

Kertoisitteko jotain taustoistanne. Olette käsitellyt -varsin filosofisia kysymyksiä, kuten olemista (being) ja olemassaoloa (existence). Missä ovat tällaisen taipumuksen juuret?

\section{PETER JARVIS:}

Olen ollut protestanttipappi ja koulunopettaja sekä täysipäiväisenä puolustusvoimissa. Minulla on monitahoinen tausta takanani. Akateemiset oppiarvoni ovat teologiasta ja sosiologiasta.

Ollessani pappina työskentelin hyvin ankarassa sisämaan kaupungissa ja totesin, että niissä oloissa teologia ei ole riittävä perusta pappistyölle. Siksi laajensin pappistyöni ohessa opintojani sosiologiaan ja jätettyäni kirkon suoritin vielä kasvatussosiologian tutkinnon. Minulla on opettajanpätevyys sekä tohtorintutkinto professioiden sosiologiassa, muttei siis oppiarvoa aikuiskasvatuksesta.

Aikuiskasvatukseen olen tullut jo 40 vuotta sitten käytännön kautta, opettaessani ensimmäistä aikuisten ryhmääni kirkon piirissä. Sittemmin olen opettanut etiikkaa ja sosiologiaa ja nykyisin opetan sosiologiaa British Open Universityssä. Se kaikki luonnollisesti vaikuttaa ajatteluuni. Akateemiseen uraani on tällä tavoin aina kietoutunut annos filosofiaa ja sosiologiaa, ja siihen samaan pyrin kaikessa kirjoittamisessanikin. Aloin kirjoittaa aikuiskasvatuksesta, ja ensimmäinen aihepiiriin kuuluva kirjani ilmestyi 1982.

Jossain mielessä olen harrastelija, sillä teen sukelluksia erilaisiin tieteenaloihin. Yritän siis löytää hitusen tietoa. joku voi sanoa kirjastani, ettei se ollut hyvä ja pystyisi itse tekemään paremman. Silloin juuri kirja on jo onnistunut tehtävässään, jos se sanoo jotain tai käynnistää jotain, jonka joku muu pystyy tekemään vielä paremmin. Olen siis kiinnostunut tutkimaan ideoita, jotka liittyvät aikuiskasvatukseen.

Onko se, että yhdistätte aikuiskasvatukseen filosofisia elementtejä, ominaista juuri Teille vai heijasteleeko se kenties laajemminkin brittiläistä ajattelutapaa?

\section{PETER JARVIS:}

Brittiläisessä aikuiskasvatuksessa elää teologiataustaisen aikuiskasvatuksen laaja perinne. Niinpä Nicholas Walkersin kanssa toimittamassani kirjassa "Adult Education and Theological Interpretations" (1993) lähes jokaisella kirjoittajalla oli pappisvihkimys tai pappiskoulutus tai hän oli ollut munkkina tai nunnana ja siirtynyt sittemmin näistä teologisista taustoista aikuiskasvatustyöhön. 


\section{Aikamme suuria opettajia ja vaikuttajia}

Olette toimittanut aikamme merkittävistä aikuiskasvattajista kaksi teosta. Toinen esitteli eurooppalaisia aikuiskasvattajia. Toinen on nimeltään "The Twentieth Century Thinkers in Adult Education" (Roudledge 1991). Artikkeleissanne olette käyttänyt luovalla tavalla mm. Erich Frommin ja Paolo Freiren ajatuksia. Ketkä muut nykyajattelijat ovat mielestänne vaikuttaneet ajatteluunne?

\section{PETER JARVIS:}

Fromm ja Freire, kyllä molemmat. Olen suuresti ihaillut Paolo Freireä. Kun siirryin aikuiskasvatustehtäviin, hän vieraili viikon ajan Surreyssä ja oli itse asiassa ensimmäinen mertentakainen vieraani. En silloin edes tajunnut täysin hänen merkitystään.

Nykysosiologeista keskeinen henkilö on Anthony Giddens. Zygniund Bauman on mielestäni erittäin keskeinen ajatuksiini vaikuttanut henkilö myöhäismodernia ja postmodernia käsittelevillä kirjoillaan. Filosofiassa olen kokenut John Deweyn äärimmäisen stimuloivaksi itselleni koulukasvatuksen puolella.

Aikuiskasvatuksen puolella sen sijaan on hyvin vaikeaa sanoa ketään tiettyä henkilöä. Tullessani aikuiskasvatuksen pariin parikymmentä vuotta sitten pääsin nopeasti tutustumaan lukuisiin ihmisiin ja jakamaan heidän kanssaan ajatuksia. Ensimmäinen kirjani sai vaikutteita eräiltä koulukasvattajilta, kuten R.S. Petersiltä. Hän nimenomaan oli tärkeä filosofina.

Ensimmäinen kirjani ammattikasvatuksesta oli myös synteesi koulukasvatuksen ajatuksista ja omasta väitöskirjastani, mikä käsitteli professioiden sosiologiaa. Toiset ihmiset ovat tärkeämpiä vaikuttajia omaan ajatteluun kuin toiset, mutta luen paljon ja imen ideoita hyvin monenlaisista lähteistä.

Tehdessäni kirjaa "Twentieth Century Thinkers..." laadin luettelon mielestäni kaikkein eniten aikuiskasvatuksessa vaikuttaneista ihmisistä. Keskustelin sen vuoksi muutamien kollegoitteni kanssa ja päädyimme 13 nimeen, joista 10-11 olimme varsin yksimielisiä. Kun arvioin tuota keskeisten henkilöiden luetteloa nyt lähes kymmenen vuoden jälkeen, enpä muuttaisi luetteloa kummemmin.

\section{Aikuiskasvatuksen erilaisuudesta}

Tunnette varsin monia suomalaisia kollegoitanne. Mitä eroja olette havainneet ajattelutavassa brittiläisten ja suomalaisten välillä?

\section{PETER JARVIS:}

Vaikea sanoa. Teidän kulttuurinne on hyvin vaikea. Teillä on pitkä historia sitoa ihmiset yhteen tavalla, mikä ei ole ominaista Britannialle. Me olemme paljon enemmän individualisteja. Voisi myös sanoa, että olemme eräällä tavoin lähempänä Modernin projektin loppua kuin Suomessa ollaan. Eroja on vaikeaa täsmentää. Kasvatus on Suomessa kuitenkin institutionalisoidumpaa kuin meillä.

Mielestäni aikuiskasvatusopiskelijoiden ajattelutavassa ei ole Britannian ja Suomen kesken suuria eroja. ja vaikka maiden välillä on hienoisia kulttuurisia eroja, käsittääkseni molemmissa yliopistollisissa laitoksissa luetaan perusrakenteeltaan kuitenkin varsin samankaltaista tietoa. Eri tiedemiehillä on luonnollisesti erilainen tapa katsella asioita. 
Peter Jarvis toivookin erilaisten yhteistyöhankkeiden kehittämistä Britannian ja Suomen yliopistojen kesken. Nyt sellaista on hyvin vähän, mutta potentiaalisia mahdollisuuksia yhdessä työskentelyyn voisi löytyä.

\section{Kulttuureiden erilaisuudesta vertailevaan tutkimukseen}

Entä voisiko aikuiskasvatuksella tieteenalana olla eroja siksi, että ne elävät eri kontekstissa ja kulttuureiden kesken on eroja?

\section{PETERJARVIS:}

En pidä kasvatusta tieteenalana (disciplin).Tarkoitan sitä, että valitessasi filosofian voit valita kasvatuksen filosofian, muttet filosofian kasvatusta. Voit opiskella kasvatuksen sosiologiaa, muttet sosiologian kasvatusta.

Käytännön kenttä pitää koota kulttuuriseen kontekstiinsa. Tarkastelemme siis jotain sellaista, joka manifestoi itseään kulttuurisen kehyksen sisällä. Matkusteltuani paljon olen tullut tietoiseksi siitä, etten voi olettaa sen, mikä on merkityksellistä yhdessä maassa, olevan merkityksellistä myös jossakin toisessa.

Niinpä täällä Helsingissä pitämäni luento pohjasi ajatuksiltaan sellaiseen, mikä pätee Britanniassa, muttei kenties yhtä lailla tai lainkaan Suomessa. Jos puhumme kulttuureiden lähenemisestä, me olemme viisi tai kymmenen vuotta teitä edellä fragmentoitumisessa, ja sen vuoksi nyt meillä merkityksellisiksi koetut asiat eivät välttämättä ole merkityksellisiä Suomessa. Mutta samat asiat ovat varmasti relevantteja Alaskassa, koska Alaska on Britannian tavoin hyvin individualistinen kulttuuri.

Tavallaan ei ole syytä etsiä eroja tieteenalojen sisältä, vaan kulttuureiden kesken, minkä johdosta toiset asiat ovat merkityksellisempiä jossakin kulttuurissa kuin jossakin toisessa. Mielestäni tulisikin kehittää juuri vertailevan tutkimuksen koko aluetta. Kuulun Englannissa koulukasvatukseen painottuvan lehden nimeltä "The Journal of Comparative Education" toimituskuntaan. Aloimme tarkastella kulttuureiden tasoa, muutoksia kulttuurin sisällä ja tapaa, millä kasvatus manifestoi itseään eri kulttuureissa. Siihen liittyy myös poliittinen päätöksenteko: mitä hallitustasolla nähdään tarpeelliseksi tukea ja mitä ei.

Ei siis ole kovinkaan syvällistä keskustella aikuiskasvatusjärjestelmien eroista. Syvällisempi ja mielekkäämpi kysymys on kulttuureiden ja politiikanteon eroavaisuus ja miten kasvatus sen yhtenä tuloksena tulee esiin. Siksi minusta meidän tulisi käyttää enemmän aikaamme muiden tieteenalojen tarkasteluun, ja sitä yritän omasta puolestani tehdä.

\section{Tieteenalojen rajat ylittävään yhteistyöhön}

Yhteistyö yli tiedekuntarajojen on hyvin tärkeää. ja se, että meillä ei ole tällaista yhteistyötä riittävästi, on selvä ongelma-alue. Yhteistyö tiedekuntien kesken on hyvin vaikeaa, sillä ei ole helppoa löytää sosiologian laitokselta henkilöä, joka tietää riittävästi aikuiskasvatuksesta suorittaakseen tohtorinarvon sosiologiasta kasvatuksessa. Yhtä vaikeaa on löytää aikuiskasvatuksen laitokselta joku, joka tuntee riittävästi sosiologiaa. jos yliopistot ovat tällä tavoin pirstoutuneet, yhteistyö on rankkaa.

Yhdysvalloissa on kenties toisin siksi, että siellä laitosten välillä on enemmän vapautta ja yliopistoissa on yhden henkilön asemasta tutkimusta ohjaava komitea, ja on helppoa saada komiteaan 
psykologi, filosofi, sosiologi jne. Kysymys palaa siis siihen, miten yliopistotyöskentely pitäisi organisoida, jotta se edistäisi suhteiden olemassaoloa myös eri laitosten kesken.

Isossa-Britanniassa aikuiskasvatuksen asema on erilainen: se on etäämpänä yliopiston rakenteesta vai voiko sanoa, että se ei ole sen sisällä lainkaan?

\section{PETER JARVIS:}

Enimmältään ei ole siellä lainkaan. On joitakin laitoksia, missä aikuiskasvatusta opetetaan kandidaattitasolla, mutta hyvin harva on vakiinnuttanut niin lujasti asemaansa, että niitä voitaisiin kutsua tietyn yliopiston laitokseksi. Surreyssä se ei ole ydinlaitos, vaan pikemminkin "periferinen", vaikka meillä on 55 alemman yliopistollisen tutkinnon opiskelijaa. Täällä Suomessa aikuiskasvatus on aivan toisella tavalla vakiinnuttanut asemansa kasvatustieteellisen tiedekunnan kehyksissä.

\section{Sivistys ja yleissivistys ajassamme}

Olette kirjoittanut oppimisesta myöhäismodernissa. Siinä yhteydessä olette nostaneet esiin kysymyksen modernin totuuksista - kuten opettajien auktoriteetin, sen että mihin tahansa kysymykseen löytyy oikea vastaus tai että tiede voi ratkaista kaikki ongelmat ennemmin tai myöhemmin. Yksi tällaisia modernin totuuksia on käsitys yleissivistyksestä. Onko ja voiko myöhäismodernissa olla yleissivistystä ja mitä se voisi olla?

\section{PETER JARVIS:}

Eiköhän tietoa ole aivan liian paljon kenelle tahansa, jotta todellisia yleissivistyneitä voisi olla. Tieto on pirstoutunut ja erilaisia näkökulmia on kovin paljon. En usko olevan mahdollista, että kasvatus voitaisiin ymmärtää kokonaisuutena ja ymmärtämiseen löytyisi tarvittava perusnäkökulma.

Oma ratkaisuni on, että yritän kirjoittaa politiikan näkökulmasta, sosiologian näkökulmasta, etiikan näkökulmasta. Meillä ei voi olla kaiken kattavaa peruslähestymistapaa, mutta voimme sen sijaan sukellella johonkin ilmiöön erilaisista näkökulmista käsin.

Me olemme oppineet eriyttämään toisistaan opettamisen ja oppimisen. Opettaminen on institutionaalinen prosessi. Yliopistosta on tullut sivistyksellisen tiedon vähittäiskauppias, enenevässä määrin kurssien myyntiliike. Voit ostaa yhden opetuspaketin yhdestä paikasta, toisen toisesta. Mennäänpä vielä pidemmälle. Ennen pitkää Philips myy interaktiivisia CD-kurssilevyjä kotikäyttöön. Näin kasvatukselliset paketit mahdollistavat oppimisen erilaisia menetelmiä yhdistämällä. Yksi myöhäismodernin piirteitä onkin mahdollisuus oppimismallien moninaisuuteen. Näin syntyviä "hartnaita koulutusmarkkinoita" käsittelen seikkaperäisesti artikkelissani Oppimisen markkinat (tämän lehden numerossa haastattelun jälkeen; toimituksen lisäys.

Kehityksessä piilee vaara, että suurista yhtiöistä tulee yliopistojen kilpailijoita tiedon vähittäismyyjinä, koska niillä on siihen enemmän resursseja. Sellainen kehitys kauhistuttaa minua. Mutta jossain määrin sitä on jo tapahtunut, sillä Britannian satelliittitelevisio-ohjelmissa on opiskelukanava (Discovery Channel). Yliopistojen etuna on luotettavuus. Mutta kauanko sen monopoli kestää? Oppiarvon voi saada jo nyt vaikkapa General Motorsilta. Ei minulla ole vastauksia, mutta yritän tutkia niitä, esittää lukuisten muiden ihmisten tavoin kysymyksiä ja herättää julkista keskustelua.

Esitän äskeisen yleissivistystä koskevan kysymyksen toisin päin: millainen on mielestänne sivistynyt (cultivated) ihminen? 


\section{PETER JARVIS:}

Tätä kysymystä kasvatusfilosofit ovat juuri kysyneet: Mikä on sivistynyt (educated) ihminen? Ehkä hän on henkilö, joka tietää, ettei voi koskaan tietää kaikkea, mutta joka tavoittelee tietoa elämänsä ajan. Englantilainen filosofi R.S. Peters on sanonut, että sivistynyt ihminen on matkalla. Ihminen ei siis pääse tiedon matkallaan koskaan perille. Silti tiedon voi katsoa tehneen ihmisestä sivistyneen.

Toivon itsestäni, että olen suhteellisen sivistynyt siinä mielessä, että yritän ymmärtää ihmisiä ja ihmiset ymmärtävät jonkin verran minua. Mutta on kokonaisia suuria tiedonalueita, joista olen tietämätön. Olen siis joutunut erikoistumaan.

Toinen esimerkki. jos eläisin New Yorkissa, olisin kuin ankka kuivalla maalla harhaillessani Harlemin yössä, missä kymmenvuotiaat pienet lapset tuntevat olonsa kotoisiksi. Heidän maailmassaan minä olen tietämätön. ja kun he tulevat kouluun, he ovat kuin ankat kuivalla maalla, kun taas minä tunnen oloni viihtyisäksi. Näillä kymmenvuotiailla on katuviisautta, minulla kirjaviisautta. Selviytyäkseen elämäntavallaan ja elämässään heidän täytyy siinä kontekstissa olla älykkäitä, mutta se ei tee heistä sivistyneitä.

Entä kirjaviisaus? Olen työläiskodin lapsi. En ollut kovinkaan hyvä suosituissa kielissä, mutta niiden sijaan luin yliopistossa hepreaa, kreikkaa ja latinaa. No, nyt olen unohtanut ne, mutta ranskaa, saksaa ja espanjaa lukeneet opiskelutoverini pitivät minua tietämättömänä ja olivat tavallaan oikeassa.

Yritän kenties sanoa, että ihmisen on sittenkin pakko erikoistua. Ei voi olla monikielistä henkilöä, käsittääkseni. Sivistys on kovin suhteellista.

\section{Teemme olemisen peruskysymyksiä}

Myöhäismodernin eräänä piirteenä pidetään arvojen pirstoutuneisuutta. Mitä havaintoja voisi tehdä nykypäivän arvokeskustelusta?

\section{PETER JARVIS:}

Tieteellisen teologian parissa tehdään samoja kysymyksiä olemisesta (being), olemassaolosta (existence) ja maailmankaikkeudesta kuin muuallakin. Mutta heillä on eri näkökulma vastata. On mielenkiintoista nähdä syvällistä tieteellistä tietoa omaavien ihmisten nostattavan samoja kysymyksiä merkityksestä kuin me teemme, me filosofian, he esimerkiksi kvanttifysiikan näkökulmasta.

Kun alamme tehdä olemassaoloon liittyviä kysymyksiä, saatamme vastata eri tavoin, mutta on valtavan paljon samaa sykettä siinä, miten iskemme asiaan kiinni. Anthony Giddens puhuu samasta kirjassaan "Modernity and Self-Identity: Self and Society in the Late Modem Age" (Polity Press, Cambridge 1991). Elämme uskonnollista - ei kristinuskoon liittyvää - aikaa siinä merkityksessä, että teemme olemassaoloon liittyviä kysymyksiä. Tällaista keskustelua on hyvin paljon.

Kirkkojen ongelmana on niitä sitova oma teologia, joka kuulostaa hieman vanhentuneelta avaruustieteeltä. Kuitenkin olemassaolon kysymykset ovat itsessään asiallisia. Ne ovat juuri samoja, joita me kaikki teemme. Uskoakseni arvoissa on paljon yleistä. ja jos on muuttumattomia arvoja, juuri niiden alueella meidän tulee keskustella postmodernistien kanssa: onko siis kaikki suhteellista vai onko asioita, jotka eivät sitä ole? 
On kummallista, että historioitsijat, sosiologian teoreetikot tai sosiologit eivät ole todellakaan ottaneet vakavasti aikuiskasvatuksen asemaa yhteiskunnan käytännöissä. Kysynkin aikuiskasvatuksen generalistien roolista?

\section{PETER JARVIS:}

Elinaikanani kasvatus kaikkien oikeutena on saanut laajan hyväksynnän. Tarkoitan sitä, että 60- ja 70-luvun filosofit määritellessään kasvatuksen tarkoittivat sillä lapsiin suuntautuvaa kasvatusta. ja kuitenkin ensimmäinen merkittävämpi kirja elinikäisestä oppimisesta ilmestyi jo vuonna 1929. ja jos mennään Comeniukseen (Johan Amos Comenius 1592-1670; toimituksen huomautus) asti, viittaus elinikäiseen kasvatukseen löytyy häneltä. On siis ollut ajattelijoita, jotka ovat osoittaneet meille tietä jo kauan.

Meiltä jää sen sijaan havaitsematta, että kasvatussosiologeissa on paljon henkilöitä, jotka vielä ajattelevat vain koulua. Kun kirjani "The Sociology of adult and. continuing education" ilmestyi 1985, se oli aivan ensimmäisiä yrityksiä tarkastella sosiologina kasvatuksen monimutkaista kenttää.

Kun nyt elinikäisen kasvatuksen alue kasvaa ja muuttuu, muutumme itse kompleksisemmiksi. Meiltä puuttuu tieteenalan perspektiivi. Ei ole olemassa yhtä ainutta jatkuvan ammatillisen kasvatuksen filosofia, ei liioin yhtään sen alan taloustieteilijää.

Eräällä tavalla näistä lähtökohdista olen yrittänyt kirjoittaa etiikan politiikasta. Tiedän etiikasta jonkin verran, koska olen aikuiskasvattaja ja olen opettanut vuosia etiikkaa. Mutta kaikki tiedon kentät ovat niin suunnattoman suuria, joten tiedän myös omat puutteeni. ja ollakseen moraalifilosofi ei oikeastaan voi tehdä muuta kuin olla moraalifilosofi. Oikeastaan kaikki niitä teen yleensäkin, on yritys rikkoa hieman jäänpintaa ja jättää sitten osaltani asia siihen. En kuvittele, että kaikki kirjoittamani olisi jotenkin maailmaa mullistavaa. Kysymyksessä on pikemminkin koputus oveen viestein: "Meillä on joitakin vaikeita kysymyksiä, joihin tarvitsemme vastauksen tai ainakin kysymyksiä."

\section{Oppimisen oikeudet, riskit ja pelot}

Peter Jarvis on elinikäisestä oppimisesta kirjoittaessaan jakanut ihmisen mahdollisuudet reagoida uusiin tilanteisiin kolmeen päävaihtoehtoon, nimittäin ei-reflektiiviseen oppimiseen, reflektiiviseen oppimiseen ja ei-oppimiseen. Ei-oppimisen kolme muotoa ovat ennakko-oletus (presumption), huomiotta jättäminen (non-consideration) ja torjunta (rejection). Ihminen suojaa itseään ympäristön muutoksilta ei-oppimisen keinoin ja on elämässään tilanteissa, missä sellainen suojautuminen on väistämätöntä ja tarpeellista.

Suomessa on tavattu puhua ihmisten jakautumisesta menestyjiin ja ei-selviytyjiin - muutama vuosi sitten tavattiin puhua A-ihmisistä ja B-ihmisistä -joiden suhde oppimiseen on varmaan myös keskenään erilainen. Jos ajatellaan aikaa, jota elämme, ja näitä kolmea päämahdollisuutta reagoida uuteen, voisiko niissä nähdä kehityssuuntia?

\section{PETER JARVIS:}

Kyllä voi nähdä. Muuttumattomuuden yhteiskunnissa, kuten primitiivisissä kulttuureissa, ei-oppiminen on elämäntapa. Kehittymättömissä yhteiskunnissa yksilö saattaa saada opetusta ensimmäiset kaksitoista vuotta, mutta sitten hän on aikuinen ja "valmis". Maailmassa, missä ei mikään juurikaan muutu, ihminen pyrkii tekemään sen, niitä joka tapauksessa tekee, tavaksi. jos ihminen oppii uuttaa, hän oppii niin kauan, että siitä on tullut tapa ja näin ei-oppimisen olotila. Se on meiltä 
puuttuvien vaistojen korviketta. Teemme tekemästämme tavan, jolloin se on samantyyppistä kuin toimisimme vaistojen mukaan, koska alamme tehdä sen vaistomaisesti.

Mutta maailma muuttuukin nyt kiihtyvällä vauhdilla, eikä tavaksi kehittämämme käyttäytyminen enää pädekään. juuri muutoksen nopeus luo oppivan yhteisön. Ulrich Beck puhuu riskiyhteiskunnasta. Eli jos meidän on pakko murtautua ulos tutusta pystyäksemme oppimaan, otamme samalla riskin. Oppimisesta tulee riski-ilmiö. Eivät ihmiset kuitenkaan halua ottaa riskejä. Ihminen on perustaltaan konservatiivinen.

Kysymyksen voi asettaa myös toisin: jos ihminen on onnellinen omalla elämäntavallaan, miksi ihmeessä heidän pitäisi muuttaa sitä? Se koskettaa minua siksi, että jotenkin automaattisesti oletamme uuden olevan samalla hyvää. Muutos tapahtuu ja ... se on vaarallista. Käsittelin Jerusalemissa pidetyssä konferenssissa juuri oppimisen pelkoa.

Muita kysymyksiä, joiden kimpussa olen pelkoa käsitellessäni askarrellut, ovat uskonto, kansallisuus ja ideologia. jos joku asettuu uhaksi niille sanomalla, että se kaikki on valheellista eikä lainkaan tärkeää, asianosainen on saatettu riskitilaan. Mitä tarpeellisempaa ihmiselle on tarrata näihin olemassaolon ulottuvuuksiin, kuten fundamentalistisiin uskontoihin tai etniseen identiteettiin, sitä vaikeampaa on oppia, koska ihminen on pelkotilassa.

Ei-oppiminen on tärkeää silloin, kun yhteiskunta ei muutu, tai elämäntilanteissa missä ihminen ei tahdo tai tarvitse muutosta. Toisinaan taas ei-oppiminen on ihmisen turvamekanismi riippua omassa itsessään, kun kaikki ympärillä muuttuu. Ajattelemme yleensä, että oppiminen on hyvä asia. Mutta mielestäni se on toisinaan myös riski ja toisinaan meidän on hyvä pysähtyä kysymään, miksi ihmeessä. ja luullakseni tulemme näkemään, että myöhäismodernin sosiologit ja filosofit alkavat tehdä myös näitä kysymyksiä.

\section{Moraalikysymyksiä ajassamme}

Otan muutoksesta muutamia kiistanalaisia esimerkkejä. Tuhlaamme suunnattomasti rahaa korkean teknologian lääkehoitoon harvojen ihmisten hyväksi, kun varaa ei ole hoitaa matalalla teknologialla suuria ihmisjoukkoja. Tai maksamme maanviljelijöille siitä, että he kesannoivat peltonsa, kun samanaikaisesti maailmassa ihmisiä kuolee nälkään. ja kaikki se on mielestämme taloudellisesti järkevää. Se on myös totaalisen järjetöntä.

Meidän on siis välttämätöntä alkaa esittää kysymyksiä siitä, millaiseen yhteiskuntaan oikein kuulumme. Haluammeko muuttua lakkaamatta?

En pidä ihmisten laputtamisesta A- ja B-ihmisiin, sillä kaikki ovat inhimillisiä olentoja. Ainoa muuttumaton moraalinen arvo siitä riippumatta, elämmekö modernissa tai postmodemissa, on ihmisten välittäminen toisista ihmisistä. Siinä olen fundamentalisti. Kirjoissani "Paradoxes of Learning" ja "... Social Context" kirjoitin ei-oppimisesta, mutta Paradoxes-kirjassa myös ei-toimimisesta (non-action), sillä ne asiat kuuluvat yhteen.

Tarvitsemme enemmän tutkimustietoa ihmisen muutoshalusta, ts. siitä, mikä saa ihmiset haluamaan pysyä sellaisina kuin ovat ja mikä saa heidät haluamaan muuttumista. Teknologia on aikaansaanut hyvää mahdollistamalla meille loistavan elämäntyylin ja samanaikaisesti teknologia on myös tuhonnut elämäntyylin. Olin äskettäin Alaskassa lähellä sitä seutua, missä muutama vuosi sitten oli öljykatastrofi satoine tuhansine kuolleine lintuineen, kaikki se teknologian tuoman elämäntapamme johdosta, Minusta on aiheellista tehdä kysymyksiä tällaisen tarpeellisuudesta. 
Kiehtovinta ajassamme ei ole se, elämmekö modernia, myöhäismodernia vai postmodernia, vaan se, että elämme aikaa, jolloin voimme tehdä itsestäänselvyyksiä kyseenalaistavia kysymyksiä tarvitsematta tuntea itseämme kummallisiksi.

\section{Kirja on tapa keskustella}

Hallinnolliset velvollisuudet ovat vieneet aikaani paljon, enkä ole ehtinyt kirjoittaa ja lukea tarpeeksi. Haluan kuitenkin vapautua näistä velvoitteistani ja palata ideoitten pariin. Etiikkakirja on yksi niistä- ja on paljon muita käsittelyä kaipaavia kysymyksiä.

Kirja merkitsee minulle paikkaa, missä yritän työstää ajatuksia muita ihmisiä varten, jotta he liittyisivät keskusteluun kirjan aiheesta. En ylipäätään näe kirjoja enää vastausten tuojina, vaan keskustelun avaajina. Kirja on minun keskustelunavaukseni.

Olen antautunut aikuiskasvatukselle. Minua kiinnostaa paljon toisen mahdollisuuden koulutus sekä naisten ja vähemmistöjen koulutus. Se, onko rikkaiden velvollisuus kustantaa köyhien kouluttautumista, toisin sanoen koulutuksen tasa-arvo kustantamisen kannalta katsottuna on juridis-eettinen kysymys. En tiedä vastausta, mutta kasvatus ja aikuiskasvatus ovat kuin pallo tässä juridis-eettisessä pelissä, sillä millään maalla ei ole varaa - ellei jollain harvalla - taata rajatonta elinikäistä kasvatusta kaikille.

Haluan joskus myös kirjoittaa uskonnosta ja kasvatuksesta. Nimittäin kun puhutaan transformatiivisesta oppimisesta, niin mikä on sen ja teologisin termein käytävän keskustelun välinen ero. Mielestäni ei mikään.

Ajon myös palata oppimisen aiheeseen uudelleen, koska olen itse oppimassa, enkä tiedä oppimisesta kovinkaan paljon.

Haastattelu: ANNELI KAJANTO ja KARIKANTASALMI

Kuvat: KALEVI KESKI-KORHONEN

Peter Jarvisin pääteos on hänen oman arvostuksensa mukaan vuonna 1992 ilmestynyt Paradoxes of Learning. Hänen artikkelinsa oppimisen paradokseista myöhäismordernissa julkaistiin Aikuiskasvatuksessa 3/ 1993. 